\title{
ATENÇÃO EM SAÚDE DA FAMÍLIA: PROPOSTA DE IMPLEMENTAÇÃO EM CURSOS DE GRADUAÇÃO EM ENFERMAGEM
}

\author{
ATTENTION THE HEALTH OF THE FAMILY: PROPOSAL OF IMPLEMENTATION IN DEGREE COURSES IN \\ ENFERMAGEM
}

\section{LA ATENCIÓN A LA SALUD DE LA FAMILIA: LA PROPUESTA DE APLICACIÓN EN LOS CURSOS DE FORMACIÓN EN ENFERMERÍA}

\section{Sandra Regina Jacopetti ${ }^{1}$, Vilma Fernandes Neves $^{2}$}

RESUMO: Este artigo discute sobre a elaboração de proposta pedagógica para a implementação de uma abordagem de Atenção à Saúde da Família, em conjunto com docentes de disciplinas profissionalizantes do Curso de Graduação em Enfermagem da Universidade Tuiuti do Paraná. Os objetivos do estudo foram: verificar e analisar a abordagem da Atenção à Saúde da Família efetuada pelos docentes da Universidade Tuiuti (PR) nas disciplinas profissionalizantes do curso de graduação em Enfermagem; e discutir sobre a re-elaboração dos planos de ensino, realizada pelos docentes participantes da pesquisa, nas disciplinas de Atenção à Saúde da Família. A opção metodológica foi a pesquisa qualitativa e, como instrumento de coleta de dados a técnica do grupo focal. Os resultados foram analisados em três categorias: Conteúdos de Atenção à Saúde da Família; Teoria e Prática na Atenção à Saúde da Família; e Práticas Pedagógicas - reorganização. Esta trajetória permitiu aos docentes sujeitos desta pesquisa a reelaborar o Plano de Ensino, inserindo a Atenção à Saúde da Família nos conteúdos ministrados. Portanto, os objetivos da pesquisa foram alcançados, uma vez que foram re-elaborados os Planos de Ensino das disciplinas profissionalizantes para a inclusão de conteúdos relativos à Saúde da Família.

PALAVRAS CHAVES: Saúde da Família; Educação em Enfermagem; Educação Superior.

ABSTRACT: This paper discuss about the elaboration of a pedagogic proposal to the development of an Family Health approach, with all professor of professionalizing lecturers of the Tuiuti University of Paraná state Nursing Graduation course. It has as objective to verify and to analyze Family Health approach developed by professors in professionalizing lecures; and to discuss about the reviewing of teaching plans, developed by research participant professors of Family Health area. The focused group based in qualitative research was the methodological approach. Three categories emerged from data: a) Health Family contents; b) Theories and Practices in Family Health; and Pedagogic Practices reviewing. In this way, the professors meant to be capable to review their teaching plan, inserting the
Family health in their lectures contents. Therefore, the objective of this research was obtained because it was an important task to professor reviews their teaching plans.

KEY WORDS: Family Health; Nursing Education; Higher Education.

RESUMEN: En este articulo se discute sobre la elaboración de una propuesta pedagógica para el desarrollo de una abordaje de la Salud de la Familia, con todos los profesor de las salas de aula de materias profesionales del Curso de Graduación en Enfermería de la Universidad de Tuiuti en Paraná. Tiene como objetivo verificar y analizar la abordaje de la Salud de la Familia desarrollado por los profesores de las materias profesionales; y discutir sobre la elaboración de planos de enseñanza, desarrollado por los profesores, de el área de Salud de la familia, participantes en esta investigación. El método utilizado fue el grupo focal fue con base en la pesquisa cualitativa. Tres categorías fueron identificadas, siendo a) Contenido de la familia de la salud; b)Teorías y prácticas en salud de la familia; y c) Practicas pedagógicas - una revisión. De esta manera, los profesores significaron ser capaces repasar su plan de enseñanza, insertando la salud de la familia en su contenido para las aulas. Por lo tanto, el objetivo de esta investigación fue obtenido porque era una tarea importante a las revisiones del profesor sus planes de enseñanza.

PALABRAS CLAVES: Salud Familiar; Educación en Enfermería; Educación Superior.

${ }^{1}$ Enfermeira, professora, Mestre em Educação. Local do estudo: Curitiba -Pr. Endereço para correspondência: Av. das Industrias, 2129, bloco A2 ap. 32 Curitiba-Pr. CEP 81310-060.E-mail sareja@terra.com.br

2Professora orientadora.Doutora em Educação. Local de atuação: Curitiba - PR. Endereço: R. Mons. Ivo Zanlorenzi 851 casa 14. Campina do Siqueira. Curitiba/PR. CEP 80740-590. E-mail vilma.neves@uol.com.br 


\section{INTRODUÇÃO}

A observação da falta de consonância entre a teoria ensinada no decorrer da vida acadêmica e a prática realizada em Saúde Coletiva originou o interesse pela implementação de uma proposta pedagógica para o curso de Enfermagem, uma vez que compreendemos ser uma das responsabilidades das instituições educativas superar essa dicotomia.

Este artigo é parte da Dissertação de Mestrado em Educação concluído no ano de 2005 pela Universidade Tuiuti do Paraná. Esta pesquisa teve como foco as atividades pedagógicas exercidas pelo docente de enfermagem, quanto a Atenção à Saúde da Família, tendo como desafio a implementação desse conteúdo ao longo do Curso de Graduação em Enfermagem, respaldando-se nas Diretrizes Curriculares Nacionais do Curso de Graduação em Enfermagem, Lei 9.131/95, parecer CNE/CES 1.133, homologado em 7 de agosto de 2001 no artigo 5o, inciso XI que trata da formação do enfermeiro.Os documentos discorrem sobre competências e habilidades específicas, incluindo a incumbência de "responder as especificidades regionais de saúde através de intervenções planejadas estrategicamente, em níveis de promoção, prevenção e reabilitação à saúde, dando atenção integral à saúde dos indivíduos, das famílias e das comunidades" (BRASIL, 2001).

Entende-se que embora exista uma visão formalmente instituída é necessário que essa seja implementada. Para tanto é necessário reorganizar as práticas pedagógicas para que atendam ao atual processo de mudança contínua da estrutura, das funções e do papel social da família, enfoque central deste estudo.

Sob essa perspectiva, COSTA NETO (2000), adota uma visão ampla e humanista, considerando a família como uma instituição básica, natural e indispensável da sociedade humana, ressaltando que a formação na área da saúde passa por um momento de preocupação com os aspectos sociais, no qual o profissional tem responsabilidades com a qualidade técnica e com a consciência social.

Considera-se, portanto, necessário refletir sobre a prática pedagógica exercida pelos docentes para 0 preparo do futuro profissional "enfermeiro" capacitando-o com competência, habilidades e atitudes que, de forma resolutiva, consigam atender e compreender o núcleo "familiar", possibilitando a sua interação e atuação multiprofissional, cujo benefício atinja a família promovendo a saúde para todos.

Nos últimos anos, movimentos importantes têm sido realizados em direção às necessárias mudanças na formação dos profissionais de saúde no Brasil. Esses movimentos, tanto no campo dos serviços públicos, em especial pela estratégia da "Saúde da Família", como no campo dos serviços privados com o objetivo de superar o modelo centrado no hospital e no consumo abusivo da tecnologia (FEUERWERKER, 2002).

O profissional "enfermeiro" com competências e habilidades na Atenção à Saúde da Família estará também preparado para atuar em Programa de Saúde da Família (PSF), hoje uma política de Saúde instituída no Brasil. Diante disso, esta pesquisa dá ênfase a Atenção à Saúde da Família por entender que com essa abordagem o profissional enfermeiro será capaz de atuar junto ao PSF e também em unidades hospitalares, pois a família está presente em todos os níveis de atenção à saúde. A Atenção à Saúde da Família é entendida, nesta pesquisa, como uma necessidade em todos os níveis de complexidade da Atenção à saúde, ou seja, precisa ser enfocada no Hospital, nas Unidades de Saúde e nos domicílios, pois entendemos que as famílias estão presentes em todas as situações do processo saúde-doença do indivíduo, no entanto o PSF faz sua abordagem somente nas Unidades de Saúde da Família, portanto é um Programa específico para a Atenção Primária à saúde. Pensa-se que disso resultam alguns benefícios de prevenção e, ou melhor, acompanhamento no restabelecimento da saúde do indivíduo e do suporte necessário à família para o cuidado de seu membro quando acometido por um problema de saúde. Outro beneficio é quanto ao aproveitamento dos recursos do governo para gastos com a saúde da população, que pode ocorrer através da diminuição da hospitalização. O profissional Enfermeiro contribui nesse sentido quando dá suporte às famílias, orientando-as adequadamente, uma vez que pode prestar cuidados no domicilio, preparo esse que contribui para uma maior humanização do tratamento.

Nesse sentido, FEUERWERKER (2002) destaca como necessária uma articulação entre as políticas de saúde e de educação na reorientação do povo, trabalho esse a ser realizado junto com os atores da saúde, pois considera que o setor de saúde no Brasil é um dos únicos que passa por uma reforma democrática e orientada à eqüidade, baseada de algum modo numa mobilização ampla de atores sociais diversificados.

Para LAVRAS (2002), no que diz respeito ao processo de formação de recursos humanos para o Sistema Único de Saúde (SUS), depara-se com um distanciamento entre a Política Nacional de Educação e a Política de Saúde. Mesmo assim, existe um consenso entre os gestores municipais de saúde quanto à formação dos profissionais para melhor adequação na qualificação da relação profissional/paciente - questão essa ligada diretamente à humanização da atenção; incorporação de uma visão epidemiológica como referência; a capacitação para o trabalho em equipe e a 
valorização da participação social no sistema. Espera-se com isso que o profissional de saúde constitua-se num agente de transformação social numa sociedade marcada pela exclusão social, pelas diversidades regionais e por diferenças culturais.

O Conselho Nacional de Educação (BRASIL, 2001), na Resolução número 3 de 7 de novembro de 2001, art. 3, inciso I, coloca para o Curso de Graduação em Enfermagem um perfil de formando egresso/ profissional como: "Enfermeiro, com formação generalista, humanista, critica e reflexiva. Profissional qualificado para o exercício de Enfermagem, com base no rigor científico e intelectual e pautado em princípios éticos. Capaz de conhecer e intervir sobre os problemas/situações de saúde-doença mais prevalecentes no perfil epidemiológico nacional, com ênfase na sua região de atuação, identificando as dimensões bio-psico-sociais dos seus determinantes. Capacidade a atuar, com senso de responsabilidade social e compromisso com a cidadania, como promotor da saúde integral do ser humano".

A necessidade da qualificação para profissionais capacitados em sistemas voltados para a Saúde da comunidade vem sendo sentida desde a construção do SUS, particularmente com as Normas Operacionais Básicas de 1993 e 1996 (NOBs), quando os dirigentes municipais de saúde passaram a ser denominados de gestores e, na procura pelo profissional capacitado a exercer o cargo, observou-se a não qualificação ou, ainda, uma qualificação com conteúdos não exatamente sincronizados com a nova realidade do Sistema de Saúde (FIOCRUZ, 1998).

A relevância desta pesquisa está em compreender e contribuir para diminuição desta lacuna em uma oportunidade de reflexão com o corpo docente sobre o cuidado dos indivíduos, família e comunidade de maneira que possibilite a formação de profissional Enfermeiro para atuar junto às famílias em Unidades de Saúde e, em extensão, no campo hospitalar. E junto a isso capacitar esses profissionais para o mundo do trabalho com a visão das necessidades das políticas de saúde atuais.

Os municípios brasileiros contam hoje com equipes específicas para atuar junto às famílias - essas equipes fazem parte do Programa de Saúde da Família. O município de Curitiba, atualmente, tem oito Distritos Sanitários, que gerenciam 57 Unidades Básicas de Saúde, 42 Unidades de Saúde da Família e cinco Unidades de Saúde 24 horas. Para que os profissionais da saúde possam atuar nas Unidades de Saúde da Família, e aí se insere o Enfermeiro, necessitam de contínua capacitação para adquirirem competências e habilidades para atuarem junto às famílias. Ocorre, no entanto, falta de preparo que se inicia no decorrer da graduação. Entende-se que a graduação é um despertar para o trabalho dentro de uma perspectiva em que esse olhar possibilite uma visão mais holística e humanista quanto ao cuidado da família e de seus membros, bem como uma maior compreensão das diferentes estruturas familiares, além do resgate histórico da profissão do Enfermeiro no cuidado das famílias.

Esta pesquisa propõe um trabalho em conjunto com os docentes do Curso de Enfermagem da Faculdade Tuiuti do Paraná, para reorganizar e implementar uma abordagem à saúde da família, ao longo das disciplinas profissionalizantes do Curso de Graduação em Enfermagem, de forma a contribuir na formação do profissional Enfermeiro para essa realidade que vem sendo discutida pelos profissionais da área e com isso atendendo ao movimento de articulação nacional de formação de recursos humanos para a saúde.

Nesse sentido, os seguintes objetivos foram estabelecidos para este estudo:

- Verificar e analisar a abordagem da Atenção à Saúde da Família efetuada pelos docentes da Universidade Tuiuti do Paraná nas disciplinas profissionalizantes do curso de graduação em Enfermagem;

- Discutir sobre a re-elaboração dos planos de ensino, realizada pelos docentes participantes da pesquisa, nas disciplinas de Atenção à Saúde da Família.

\section{TRAJETÓRIA METODOLÓGICA}

Optou-se pela abordagem qualitativa. As ações desenvolvidas encaminharam-se para particularidades subjetivas, pois considerou-se fundamental que os participantes fossem ativos no processo de implementação da abordagem de Atenção à Saúde da Família em suas práticas pedagógicas junto às disciplinas profissionalizantes do curso de Enfermagem. Também, deseja-se momentos de construção conjunta de conhecimentos na implementação de uma proposta pedagógica, com vistas à Atenção à Saúde da Família, tanto do pesquisador, quanto dos participantes envolvidos no processo.

Esta proposta encontra suporte em POLIT \& HUNGLER (1995), quando propõem que, as pesquisas qualitativas tenham a premissa que o conhecimento sobre as pessoas só é possível a partir da descrição da experiência humana tal como ela é vivida e tal como é definida pelos seus próprios atores. Assim propiciam campo livre ao rico potencial das percepções e subjetividades dos seres humanos. Essa ótica encontra afinidades com BOGDAN \& BIKLEN (1991, p. 48), ao afirmarem que, na pesquisa qualitativa o pesquisador está inserido em seu local de estudo, por propiciar um melhor entendimento da realidade que enfrenta. 
Portanto tem melhores chances para compreender esta realidade e, assim, "os locais têm que ser entendidos no contexto da história das instituições a que pertencem".

Com base nos autores citados, a escolha do local da pesquisa foi o próprio ambiente de trabalho do pesquisador. Os sujeitos foram os docentes das disciplinas profissionalizantes do Curso de Graduação em Enfermagem da Universidade Tuiuti do Paraná. Num primeiro momento a intenção foi conhecer os conteúdos ministrados pelos docentes das disciplinas profissionalizantes e qual a abordagem por eles utilizada para os temas propostos e o que consideravam mais relevante para posteriormente se conhecer seus conceitos de Atenção à Saúde da Família e identificar se havia uma abordagem ou não sobre esse tema. Esses foram os primeiros passos da investigação para posteriormente construir-se em conjunto uma abordagem de Atenção à Saúde da Família, pois segundo BOGDAN \& BIKLEN (1991, p. 49) "Os investigadores qualitativos interessam-se mais pelo processo do que simplesmente pelos resultados ou produtos".

Recorreu-se à técnica do grupo focal, como instrumento para a coleta de dados, utilizou-se temas geradores para se iniciar a discussão, acompanhado da observação, análise documental através dos planos de ensino atuais e reelaborados, como estratégias para obtenção dos dados necessários e, que deram suporte para a análise de resultados.

Os depoimentos no grupo focal, realizados nesta pesquisa aconteceram uma vez por semana em horário pré-determinado pelo grupo e em local que se pudesse trabalhar sem que houvesse interrupção externa, o que poderia interferir na concentração do entrevistador, observador e entrevistado, bem como possibilitar o desvio da atenção do assunto tratado no momento. A duração de cada reunião variou entre uma hora e uma hora e trinta minutos, dependendo da discussão em questão e respeitou-se o cansaço expresso pelos participantes, por entender que não seria produtivo para a pesquisa e os desrespeitaria.

Foi realizada uma reunião com o corpo docente antes de serem iniciadas as discussões em grupo, para serem esclarecidos os objetivos do estudo. Nessa ocasião Ihes foram entregue um documento que lhes garantiu o anonimato, bem como a solicitação de autorização para posterior publicação, gravação das entrevistas e serem fotografados. Foi solicitada, ainda, autorização da direção da faculdade, da coordenação do curso, bem como do comitê de ética da instituição para iniciar-se o trabalho de campo.

A construção de uma abordagem de Atenção à Saúde da Família nas disciplinas profissionalizantes do Curso de Enfermagem, tem como proposta a construção conjunta, com os docentes, partindo da realidade de cada participante, do que ele conhece sobre o tema e de sua prática, para então refletir-se criticamente, sobre essa prática e posteriormente negociar-se dentro do contexto objetivo (a coordenação do Curso) as possibilidades da sua implementação no Projeto Político Pedagógico do curso. Nesse sentido encontra-se suporte em CHIZZOTTI (2000, p. 84), ao afirmar que: "O resultado final da pesquisa não será fruto de um trabalho meramente individual, mas uma tarefa coletiva, gestada em muitas microdecisões, que a transformam em uma obra coletiva".

Portanto, não houve uma rigidez quanto à seqüência dos temas geradores, embora a técnica do grupo focal não considere o tema gerador como uma entrevista buscou-se em LUDKE \& ANDRÉ (1986, p. 34), suporte teórico para justificar a forma que se aplicou na escolha do tema gerador de cada reunião com o grupo focal. Essas autoras afirmam que entrevista semiestruturada, "[...] se desenrola a partir de um esquema básico, porém não aplicado rigidamente, permitindo que o entrevistador faça as necessárias adaptações", o que coincide com a proposta para a realização da discussão dos temas geradores com o grupo focal, porque segundo diferentes autores, essas discussões devem ser preferencialmente semi-estruturadas pela riqueza de captação das informações adquiridas pelos participantes do grupo focal no decorrer da discussão.

Outra colocação sobre a questão vem de BOGDAN \& BIKLEN (1991, p. 136), ao salientarem que "Num projeto de entrevista qualitativa a informação é cumulativa, isto é, cada entrevista determina e liga-se a outra".

Os depoimentos foram gravados e transcritos após cada encontro. Entende-se que esse recurso possibilita ao pesquisador despender uma maior atenção na discussão e na eventualidade de não se captar qualquer fala que seja relevante para a análise dos resultados, elas podem ser recuperadas através da gravação. Tratando desse tema LUDKE \& ANDRÉ (1986, p.37) colocam que "A gravação tem a vantagem de registrar todas as expressões orais, imediatamente, deixando o entrevistador livre para prestar toda a sua atenção ao entrevistado". No entanto, essas mesmas autoras ressaltam que as gravações têm a desvantagem de não captar expressões faciais, os gestos, as mudanças de postura que são de relevância quando na análise dos resultados.

Adotou-se, assim, a técnica da observação como complemento da gravação, o que é coerente com a técnica do gruo focal. A observadora foi uma acadêmica do quarto ano de Enfermagem, a qual foi previamente treinada pela pesquisadora, pois segundo LUDKE \& ANDRÉ (1986, p. 25). "Para que se torne um instrumento válido e fidedigno de investigação científica, a observação precisa ser antes de tudo controlada e 
sistematizada. Isso significa a existência de um planejamento cuidadoso de trabalho e uma preparação rigorosa do observador".

No treinamento da observadora deixou-se claro o objeto de estudo e os pontos a serem observados durante as discussões com o grupo focal. Salientou-se, ainda, que toda observação é importante, mesmo que possa a priori parecer trivial, porque poderá mais tarde ser de grande valia na análise dos dados e fornecer subsídios para uma melhor compreensão, interpretação e, conseqüentemente análise dos dados coletados.

Embora houvesse um direcionamento para a observação, esta não se deu de forma estanque ou, seja, um padrão sem qualquer desvio. As observações foram semi-estruturadas e não tiveram uma estrutura rígida, pois segundo MAZZOTTI \& GEWANDSZNAJDER (2001, p.166), "[...] os comportamentos a serem observados não são pré-determinados, eles são relatados da forma como ocorrem, visando descrever e compreender o que está ocorrendo numa dada situação".

O tempo que se utilizou para a discussão e observação não ultrapassou duas horas, conforme recomendado pela literatura sobre o grupo focal. Levouse ainda em consideração a disponibilidade de tempo dos entrevistados e, após um teste piloto constatou-se que com mais de uma hora de observação não se conseguiria manter a concentração necessária, que é de suma importância na observação, pois se tem que manter a atenção nos mais variados detalhes no decorrer da entrevista. Entendeu-se que esta medida proporcionou maior segurança e maior confiabilidade, quando da análise dos dados.

BOGDAN \& BIKLEN (1991, p. 133) alertam sobre essa questão ao afirmarem que "[...] não deve ficar no local mais tempo do que aquilo que sua memória the permite ou do tempo que dispõe [...]".Esses autores salientam que em razão do trabalho de campo ser mais divertido que as anotações, há uma tendência do pesquisador de permanecer mais tempo, no entanto é necessário que o pesquisador tenha disciplina ao efetuar seu trabalho de campo.

Durante as reuniões do grupo focal, registraram-se as falas dos participantes através de gravações e as observações do comportamento de forma escrita. As observações foram realizadas pela acadêmica de Enfermagem. A observação realizada por outra pessoa, que não o pesquisador, possibilitou maior concentração nas falas dos participantes da pesquisa, pois a mediadora foi a própria pesquisadora, confirmando-se, assim, a necessidade de um moderador e um observador.

Após cada reunião com o grupo focal, foram realizadas as transcrições das gravações, bem como anotações do que se considerou ser relevante e que não se registrou naquele momento, como recomendado por LUDKE \& ANDRÉ (1986).

MINAYO (1999, p. 129), afirma que as atividades em grupo devem ser valorizadas nas abordagens qualitativas, pois permitem discussões sobre opiniões, relevâncias e valores dos participantes. Destaca como forma operacional dessas atividades o Grupo Focal, que se faz em reuniões com pequenos números de participantes, cujas sugestões e idéias são de interesse da pesquisa. Torna-se, assim, em uma "técnica de inegável importância para se tratar das questões da saúde sobre o ângulo do social, porque se presta ao estudo de representações e relações dos diferenciados grupos de profissionais da área, dos vários processos de trabalho e também da população".

Segundo PATTON (2002), o grupo focal realiza reuniões com um pequeno grupo de pessoas, que vão de seis a oito pessoas e os temas tratados são específicos, portanto o grupo deve ser homogêneo para que possam discutir e refletir sobre o tema gerador proposto pelo pesquisador, e acrescenta que o grupo focal possibilita a reflexão sobre os questionamentos do pesquisador ao mesmo tempo em que ouvem as respostas uns dos outros e têm a possibilidade de complementarem essas respostas, além de expressarem a sua própria opinião a respeito do assunto.

Outra vantagem destacada para o uso da técnica do grupo focal é de oportunizar uma discussão com oito pessoas de uma só vez, ao invés de uma única em uma hora e meia a duas horas, como ocorre nas entrevistas individuais

MEIER \& KUDLOWIEZ (2003) afirmam que a técnica do grupo focal além de permitir que as respostas dos temas colocados tenham maior consistência, uma vez que são elaborados por muitas pessoas, possibilitam também o surgimento de idéias novas e originais. Essas autoras acrescentam que isso possibilita ao pesquisador conhecer com maior profundidade e in loco as atitudes, comportamentos e percepções do pesquisado, com uma demanda menor de tempo e custos em relação às outras técnicas. Para estas autores o grupo focal, deve ser composto tendo em vista uma intenção e que os participantes tenham pelo menos um ponto de semelhança e pode-se, desta maneira, afirmar-se que a técnica do grupo focal utilizada nesta pesquisa foi adequada aos interesses do tema em estudo. Trabalhou-se com docentes que ministram diferentes disciplinas de conteúdos variados e, portanto com um processo de trabalho diversificado, onde todos têm como foco a formação do profissional enfermeiro. E vê-se que é extremamente enriquecedor para a construção do conhecimento tanto para o pesquisador quanto para os pesquisados participantes do grupo focal. 
Utilizou-se, ainda, a técnica da análise documental como suporte para a técnica do grupo focal o que, segundo MAZZOTTI \& GEWANDSZNAJDER (2001, p. 169) "[..] pode ser combinada com outras técnicas de coleta, tanto como uma técnica exploratória (indicando aspectos a serem focalizados por outras técnica), como para "checagem"ou complementação dos dados obtidos por meio de outras técnicas". LUDKE \& ANDRÉ (1986, p.40), corroboram esta afirmação ao afirmarem que "a escolha do documento não é aleatória. Há alguns propósitos, idéias ou hipóteses guiando a sua seleção".

Nesta fase da pesquisa foi feito um diagnóstico situacional para identificar que disciplinas e que conteúdos são ministrados com temas relacionados à Atenção à Saúde da Família pelos docentes do Curso de Enfermagem da Universidade Tuiuti do Paraná através da análise dos Planos de Ensino das disciplinas profissionalizantes.

\section{Trabalho de campo: o grupo focal}

$\mathrm{Na}$ proposta de trabalho com docentes da Universidade Tuiuti do Paraná as atividades realizadas iniciaram - se no mês de junho de 2004 , seguindo quatro momentos.

\section{Primeiro momento}

Foi solicitada autorização formal para pesquisa junto à direção da Universidade e a Coordenação do Curso de Enfermagem, especificando os objetivos da pesquisa e a metodologia proposta. Garantindo com os responsáveis pela liberação do campo as condições para o estabelecimento das características metodológicas de grupo focal.

\section{Segundo momento}

Entrou-se em contato com docentes do Curso de Enfermagem, que ministram disciplinas profissionalizantes e fez-se os convites para fazerem parte da pesquisa. Explicaram-se os objetivos e metodologia colocadas em prática no decorrer do trabalho de campo. Momento em que foram apresentadas formalmente as moderadoras, a própria pesquisadora, e a observadora - a acadêmica do quarto ano de Enfermagem.

Neste primeiro contato a receptividade foi bastante favorável e todos os presentes na reunião expressaram seu interesse em participar da pesquisa.

Definiu-se com os docentes o local das reuniões, o laboratório de Enfermagem, onde a maioria das reuniões com os docentes do Curso de Enfermagem é realizada, no entanto permaneceu-se nesse local somente por uma reunião, pois o barulho comprometia a concentração dos participantes. Então outro local foi escolhido e nele realizaram-se as reuniões até o término do trabalho de campo. Combinou-se horário e dia da semana e o que melhor se adaptou aos participantes foi às terças-feiras, às 17:00 horas.

Apresentou-se, ainda, a técnica do grupo focal, o número de encontros previstos, que seriam de 10 a 12 , e deixou-se claro que esse era o recomendado por vários autores que trabalham e pesquisam sobre o grupo focal, no entanto se poderia terminar antes ou um pouco depois do previsto. Entregou-se o termo de consentimento a ser assinado pelos participantes do grupo - no termo há o esclarecimento de que seria respeitado o anonimato dos participantes - e, ainda, solicitou-se o consentimento da gravação das entrevistas durante os encontros. Informou-se que os dados recolhidos das gravações seriam de uso estrito da pesquisa e que os nomes dos participantes seriam mantidos em sigilo.

Esclareceu-se, ainda, sobre o tempo das reuniões: que não ultrapassaria uma hora e meia. E distribuiu-se um calendário dos encontros subseqüentes, com base em uma previsão de dez encontros.

Definiram-se os participantes para o grupo focal, nessa reunião com os quinze docentes presentes. Duas deixaram claro que não participariam da pesquisa por motivos pessoais e três não garantiram a presença, em razão do horário, por terem atividade profissional em outro local, mas que fariam o possível para participar. Explicou-se que o propósito das reuniões seria a construção de uma abordagem de Atenção à Saúde da Família nas disciplinas profissionalizantes.

\section{Terceiro momento: reunião com o grupo}

Este trabalho de campo iniciou-se no dia 08 de maio de 2004, às 17: 00 horas no laboratório de Enfermagem com a participação de 10 professores.

As reuniões subseqüentes foram a partir do dia 08/06/2004, com uma previsão de término para o dia 17 de setembro de 2004. Foi distribuído um cronograma, dos dias em que aconteceriam as reuniões, para todos os participantes do grupo que se encontravam presentes.

No primeiro encontro, tal como sugere a metodologia de grupo focal, introduziu-se os participantes nos estudos descritivos exploratórios, para recolher dados sobre a atual abordagem utilizada em suas disciplinas. Os dados fazem parte da identificação da abordagem Atenção à Saúde da Família, bem como outros dados que sugerem a existência das práticas voltadas à saúde da família.

Para esse encontro foi solicitado previamente a todos os docentes que trouxessem seus Planos de 
Ensino, no entanto somente um docente o trouxe. Solicitou-se que os trouxessem na próxima reunião ou então enviassem via correio eletrônico para a pesquisadora e enfatizou-se mais uma vez a importância desse material para a análise dos dados da pesquisa.

A proposta inicial de dez encontros foi redefinida com o grupo na medida em que se foi trabalhando os temas de cada reunião; e na nona reunião fechou-se o grupo, por entender-se que se havia chegado ao ponto de saturação.

Os temas propostos para cada encontro foram estabelecidos a partir dos objetivos deste estudo, do problema de pesquisa e das questões a serem investigadas, que possibilitassem responder a esse problema, e deu-se seguimento conforme teoria exposta neste capítulo.

Os temas elaborados e expostos para discussão com o grupo focal foram os seguintes:

- Que conteúdos você trabalha na sua disciplina? O que considera mais relevante? Poderia fazer uma abordagem geral dos seus conteúdos?

- No seu plano de ensino estão inseridos conteúdos que se referem à Atenção a Saúde da Família? Se sim, de que forma? Se não, considera importante inseri-los? Por quê? De que forma você sugere inseri-lo?

- Como se poderia estar realizando um Plano de Ensino que contemple a Atenção à Saúde da Família dentro da sua disciplina, de maneira que haja uma integração com as demais disciplinas profissionalizantes?

É Importante ressaltar que esses temas foram norteadores da discussão, no entanto, conforme desenrolavam-se discussões outros questionamentos surgiram e foram incluídos por serem entendidos como necessários e importantes para a compreensão do contexto a ser estudado.

\section{Quarto momento}

Apresentar a proposta de um plano de ensino que contenha conteúdos sobre Atenção à Saúde da Família, elaborada pelo grupo, junto à Universidade para o curso de Enfermagem.

Quando se iniciaram os encontros para o grupo focal, eram dez participantes no primeiro dia, para o segundo encontro foram seis dos participantes, sendo que em algumas reuniões contou-se com quatro pessoas.

Ao término de nossos encontros estavam presentes seis dos participantes iniciais.

O término, previsto no início dos trabalhos, não ocorreu na data programada, em razão de uma reunião com os professores solicitada pela coordenação do Curso e que coincidiu com os encontros e devido ao número excessivo de feriados. Assim, por causa destas intercorrências terminou-se o trabalho de campo no final do mês de setembro.

Os participantes dos encontros tiveram suas falas gravadas. Na transmissão das falas dos participantes foram mantidos seus conteúdos com fidedignidade. Interferiu-se apenas nas acomodações das falas, como orienta a bibliografia aplicada à produção de textos a partir da oralidade: suprimiram-se os marcadores conversacionais sempre que se mostraram desnecessários (e, né, que tal); adequaram-se os tempos verbais ("tá" para está, por exemplo), por acreditar-se serem essas as correções que os docentes fariam, se para tanto tivessem oportunidade.

Este estudo busca por uma abordagem para a Atenção à Saúde da Família nas disciplinas profissionalizantes do Curso de Enfermagem da Universidade Tuiuti do Paraná que corresponda às concepções teóricas construídas ao longo das reuniões com os docentes.

\section{ANÁLISE E DISCUSSÃO DOS RESULTADOS}

A análise de conteúdo proposta para este capítulo foi possível a partir do trabalho de campo desenvolvido com o auxilio da técnica de grupo focal. As falas dos docentes são aqui representadas por números e a do pesquisador pelo seu sobrenome (JACOPETTI).

Num primeiro momento realizou-se a leitura flutuante de todo o material coletado para a análise, conforme recomendado por Bardin apud RODRIGUES \& LEOPARDI (1999), para, posteriormente, agruparem-se as falas contendo aproximações de idéias e condutas relatadas pelos sujeitos da pesquisa. A partir disso emergiram temáticas que possibilitaram o agrupamento das discussões ocorridas nas reuniões com o grupo focal.

Após exaustiva leitura dos agrupamentos temáticos selecionaram-se quatro categorias de análise, tendo em vista os objetivos propostos para esta pesquisa. Citar-se-á a seguir as categorias que foram trabalhadas nesta pesquisa para, posteriormente, proceder-se à análise de cada uma delas. As categorias foram as seguintes: 1) Conteúdos e ASF - dificuldades; 2) Teoria e prática na Atenção na Saúde da Família (ASF); e 3) Práticas pedagógicas - reorganização; as quais são discutidas na seqüência.

\section{Conteúdos e ASF - Dificuldades}

Esta categoria emergiu da temática: valorização das técnicas e patologias com conseqüente dificuldade na abordagem da ASF, que se abstraiu das falas dos docentes, sujeitos desta pesquisa, ao relatarem os conteúdos ministrados nas disciplinas profissionalizantes 
e de suas dificuldades na abordagem da ASF na exploração desses conteúdos.

Para essa categoria ficou-se detido nos conteúdos que estão inseridos, de fato, nos planos de ensino desses docentes.A preocupação no preparo do profissional Enfermeiro com competências e habilidades para o cuidado da patologia e suas técnicas adequadas está presente tanto na fala dos docentes, quanto nos seus planos de ensino. Vejamos como se expressa esta docente:

A divisão dos conteúdos foi realizada a partir de dados epidemiológicos. Nós temos na Enfermagem Psiquiátrica I, a gente vê... As disfunções psíquicas nas entrevistas com pacientes psiquiátricos, os transtornos de ansiedade e os transtornos de humor e na Enfermagem Psiquiátrica II que esta prevista agora para o próximo semestre, que nós teremos o $4^{\circ}$ período iniciando, nós temos previsto então esquizofrenia, a dependência química e os transtornos orgânicos, né? Além disto, nós temos uma disciplina no primeiro período que é saúde mental... tá , atualmente a área de saúde mental tem investido muito na saúde mental do enfermeiro e nas condições que a gente propicia de saúde mental para o paciente .[...] Então trazer este conteúdo para a Saúde Mental, para que a gente possa, na Enfermagem Psiquiátrica I e Enfermagem Psiquiátrica II explorar mais as patologias, mais os cuidados de enfermagem. (Reunião de 08/06/04, PROFESSOR 8).

Observa-se que uma importância maior é dada ao preparo centrado na patologia para atender o paciente. A Atenção à Saúde tem o enfoque no indivíduo, seja este o paciente ou o Enfermeiro, que é o cuidador profissional. No entanto para o cuidador familiar não há um enfoque no seu preparo para o cuidado ou mesmo no cuidado com o familiar para o enfrentamento da doença mental e das mudanças que possam ocorrer na dinâmica familiar em conseqüência dessa patologia.

Sobre essa questão, CARVALHO (2002) salienta que a família que cuida, precisa também ser cuidada, para que possa processar esse cuidado. Percebe-se nessa fala que em nenhum momento a ASF é abordada de maneira que venha a dar suporte aos familiares quando da internação do paciente, ou mesmo, quando da alta hospitalar.

No entanto, é importante ressaltar que tanto na fala dessa docente, quanto dos demais, coloca-se a importância de abordar a família nos conteúdos por eles (as) ministrados. Há uma abordagem da ASF no ensino clínico - que é momento em que os alunos vão para os hospitais, Unidades de Saúde e outros locais para efetuar a prática da Enfermagem - em que se discorre com maiores detalhes sobre a análise da categoria a seguir. Observa-se, também, que isso ocorre em outras disciplinas. As docentes em seus depoimentos demonstram essa afirmação:

A gente trabalha com Recém-nascido, a criança, a mulher... A mulher especialmente no campo da saúde reprodutiva e a saúde reprodutiva engloba da adolescência, dos processos da adolescência... A menstruação... Até o climatério e aí você passa pelo processo de parto e nascimento, então a mulher gestante, a mulher parturiente e a mulher puérpera, (Reunião de 08/06/04, PROFESSOR 5)

No geral a gente começa o processo-saúde doença, daí a gente fala do envelhecimento, todas a s etapas do envelhecimento.. é Sistema Único de Saúde , Atenção primária, secundária, as políticas de saúde. Daí a gente entra nas Assistenciais propriamente dita. Na Assistência dos pacientes neurológicos são distúrbios respiratórios, distúrbios cardíacos (Reunião de 08/06/04, PROFESSOR 4).

Mas assim, sempre enfocando as doenças de maior incidência, porque a gente não tem tempo de dar conta de tudo. E agora a partir desse semestre a gente quer ver se consegue abordar essas patologias nos três níveis. Então por exemplo Diabetes, quando o diabético está na Unidade de Saúde, quando o diabético vai para o hospital para um tratamento clínico ou quando o diabético precisa ir apara UTI. A gente está tentando trabalhar nesse contexto, ainda estamos engatinhando. (Reunião de 08/06/05, PROFESSOR 9)

Mais uma vez se percebe claramente que nos conteúdos abordados as patologias se sobrepõem à ASF. Entende-se que os conteúdos abordados pelos docentes são importantes para o processo de trabalho do Enfermeiro, no entanto seria possível incluir a família no processo saúde-doença. Pois o indivíduo quando acometido por uma patologia, nem sempre pode realizar seu autocuidado, necessitando de alguém para fazê-lo, é aí que um membro da família entra como cuidador. Entende-se ainda que é preciso dar suporte as famílias para esse cuidado, pois quando a saúde de um de seus membros está comprometida, pode causar uma fragilidade afetiva e/ou econômica que venha a trazer um desequilíbrio familiar, comprometendo a recuperação do indivíduo e a saúde dos demais membros da família.

Pensando-se ainda na saúde dos membros da família, pois se sabe que o stress muitas vezes acomete o estado de saúde das pessoas, quando submetidas a 
situações de pressão. A família, quando frente ao tratamento da doença de um de seus familiares, pode estar exposta a essas fragilidades.

Portanto, precisa-se prepará-las para o enfrentamento da doença, e do seu tratamento que, muitas vezes é longo, ou até mesmo para a morte, sem que isso traga prejuízos maiores à saúde da família ou o desfacelamento das mesmas. CARVALHO (2002) salienta que os serviços públicos têm dado uma ênfase maior no acolhimento aos familiares ou de alguns de seus membros através da escuta empática - menos mecânica, burocrática e fria - de maneira a possibilitar uma cooperação na solução dos problemas por parte dos usuários dos serviços.

Nesse contexto é que o profissional Enfermeiro deve atuar junto às famílias, ou seja, orientando no cuidado escutando as famílias sobre as suas necessidades não só técnicas, mas, também nas oriundas das relações afetivas. À medida que os docentes foram colocando os seus conteúdos para o grupo focal, surgiram as dificuldades da abordagem na ASF para esses conteúdos. Abstraímos das falas dos sujeitos da pesquisa diferentes justificativas para a não abordagem da ASF, conforme o exposto abaixo:

Mas eu acho que é uma coisa bem complicada, na Semiotécnica (disciplina) é uma coisa bem técnica e quando chega o familiar que você não tem contato então... eles (alunos) ficam até apavorados com medo do familiar, o que o familiar vai falar, o que ele vai falar com o familiar. Então existe assim uma barreira mesmo. Então... eu acho assim aquele contato dele ali , é o primeiro contato para muitos no hospital. Eles estão preocupados que têm que aprender a técnica... É bem técnico... Então eu acho também... Eu vejo assim... É meio complicado... Às vezes a gente... Como abordar, como inserir o aluno, ali naquele momento, no horário da visita Por que o que eles querem realmente é tomar o lanche para não ter contato, pois se perguntarem alguma coisa o que é que eu vou falar? (se refere aos alunos com os familiares) $O$ que é que eu posso falar? Até onde eu posso ir? (Reunião de 08/06/04, PROFESSOR 10).

O não enfrentamento do processo saúde-doença junto à família, pelos alunos, é justificado na fala da docente,

pois ,segundo ela, os alunos não estão preparados e os conteúdos referentes à ASF não estão inseridos na disciplina, por ser essa uma disciplina bastante técnica. A nossa compreensão a respeito da questão é que a técnica tem que ser compreendida como um instrumento do processo de trabalho do cuidado do Enfermeiro e que a família faz parte do contexto de vida do paciente, portanto é importante inserir o familiar neste processo de trabalho, através de orientações para um futuro cuidado domiciliar ou então para diminuir a ansiedade do familiar no decorrer do tratamento da doença e que esse preparo tem que ser realizado pelo docente, pois o aluno encontra-se, nesse momento do processo ensino-aprendizagem, em desigualdade com o professor, no que se refere ao conhecimento: o professor precisa orientar o aluno e conduzi-lo para esse novo conhecimento, visando sua apropriação.

A falta de preparo do conhecimento da patologia, considerando-se que esses alunos estão iniciando os seus conhecimentos a respeito das mesmas, não pode ser um impedimento para a inclusão da Atenção à família. A família deve ser incluída aos poucos, de acordo com o conhecimento próprio de cada etapa do ensino-aprendizagem. Enfatizar que a família precisa de Atenção, para que, posteriormente, em outras disciplinas, possam trabalhar outros conteúdos, com maior profundidade junto às famílias e assim construindo o seu conhecimento técnico científico da ASF.

Para que isso ocorra, é necessário preparar os futuros profissionais para essa visão familiar e que os alunos possam compreender e assimilar a família como um parceiro na recuperação da saúde de um de seus membros, além de trazer maior segurança aos familiares quanto ao procedimento correto durante o tratamento. A falta do preparo dos alunos, o caráter técnico da disciplina ou conhecimento relativo de uma patologia, não pode ser justificativa para a exclusão da família no processo de ensino-aprendizagem dos alunos: os docentes precisam se preparar técnica e cientificamente para essa realidade que é colocada a cada dia. A análise dos planos de ensino dos docentes que participaram desta pesquisa demonstra que a ASF não é por eles abordadas, pelo menos, não se tem formalmente pontuado em seus conteúdos como um conhecimento a ser construído no decorrer do ensino da Graduação em Enfermagem na Universidade pesquisada.

\section{Teoria e Prática na Atenção à Saúde da Família.}

Chegamos a esta categoria através da temática: o ensino prático como meio para o Processo Ensino Aprendizagem na Atenção à Saúde da Família. Apreende-se da fala dos docentes da Universidade Tuiuti do Paraná, do Curso de Graduação em Enfermagem das disciplinas profissionalizantes, que esses utilizam em seu processo de ensinoaprendizagem as aulas práticas, em forma de Ensino Clínico, como um meio para a aprendizagem dos alunos sobre a Atenção à Saúde da Família. Importante 
salientar que para $90 \%$ dos participantes desta pesquisa; a aula prática, ou seja, o ensino clínico, está inserida nas suas disciplinas como obrigatória para a formação do profissional Enfermeiro. Num primeiro momento, os docentes afirmam que a família é abordada em seus conteúdos, no entanto essa abordagem tem uma ênfase maior no ensino clinico. Para as aulas teóricas, a Atenção a Saúde da Família não esta contemplada, e fica à mercê das oportunidades de "campo", conforme relato abaixo, ocorrido na reunião do "grupo focal" do dia 08/06/04:

Você trabalha família com eles? (JACOPETTI). Sim a todo o momento (PROFESSOR 10)

Em teoria também?(PROFESSOR 9).

Em teoria não (PROFESSOR 1)

Mais ali no ensino clínico, a gente pouco envolve, pouco fala sobre família. A gente fala muito com o paciente, a relação é aluno/paciente, mas família... realmente... falando de mim... a gente acaba só ali no momento em que a situação está acontecendo, né? (PROFESSOR 10).

Diante dessa fala percebe-se que a teoria e a prática são dicotomizadas. A abordagem à ASF, segundo um dos pesquisados é realizada a "todo momento", no entanto o suporte teórico prévio para a compreensão da ASF não é exposto aos alunos, dessa maneira, o referencial adequado à ASF, o conhecimento teórico sobre o tema, não é colocado em discussão, para possibilitar uma reflexão mais elaborada sobre a realidade e sobre o exercício de sua prática profissional. Entende-se que uma abordagem respaldada somente na prática, não propicia ao aluno as oportunidades de no campo entrelaçar teoria e prática, considerando-se o tempo que é relativamente pequeno para o desenvolvimento do conteúdo necessário para uma exploração maior e conseqüente compreensão da unidade familiar e da ASF.

A teorização aparece no discurso dos docentes, no entanto parece não ter um foco que possibilite o direcionamento para a questão familiar com um suporte teórico que leve o aluno a refletir sobre o assunto e dar segmentação sobre o tema no decorrer de sua formação, pois cada professor dá seu direcionamento de acordo com o que ocorre na sua prática, no seu campo, o que não favorece maior aprofundamento e a sua apropriação.

Essa falta de direcionamento impede que o aluno construa um conhecimento que liberta, pois conforme nos aponta WACHOWICZ (2001), o conhecimento é libertador quando é construído no seu pensamento e pelo seu pensamento, como em um círculo, onde não há pontas soltas, pois a sua inteligência não se encontra com a coerência necessária que sinta um fechamento e sim uma necessidade de maiores apropriações.

Entende-se que se cada professor trabalhar de forma isolada e pontual, diante de uma realidade específica as pontas ficam soltas, o conhecimento passa a ser estanque e acabado ao término do Ensino Clínico. O que chama a atenção para essa questão é que o docente ao privilegiar as atividades de campo para demonstrar a teoria, deixa de efetivar uma abordagem teórica sobre o assunto. Percebe-se, então, um contra senso no discurso proferido. O depoimento do docente, da reunião de 08/06/04, ilustra o exposto:

Eu faço assim a gente tem uma dimensão teórica, a gente tem uma teorização do assunto em sala de aula, coisa que na minha visão é bastante quadriculada ... até gosto muito de iniciar os ensinos clínico, porque a gente tenta abrir um pouquinho a cabeça dos alunos. Então tem que teorizar e eu teorizo com referencial baseado em epidemiologia [...] ( PROFESSOR 2). Como assim?(JACOPETTI).

Este ser mulher nesta família como ela está na família, assim eu trabalho. Então uma mulher bem relacionada ou satisfeita .. é na sua dimensão sexual, na dimensão de planejamento familiar, na sua dimensão de prevenção de doença sexualmente transmissível, na dimensão da prevenção de câncer de colo uterino e de mama, na prevenção do planejamento familiar. (PROFESSOR 2)

Como que a família entra ai? (JACOPETTI)

A família na verdade não entra né ? Porque ... infelizmente a população com que nós trabalhamos ela não se preocupa com o nosso alvo mulher, o nosso alvo criança [...](PROFESSOR 2).

Essa teorização sobre Atenção à Saúde da Família esta focada no indivíduo, percebe-se que quando o docente refere-se à teorização ela não é familiar, mas sim individual. Embora haja uma afirmação de teorização sobre família, essa fica vinculada à vinda do familiar, que é o que o trabalho de campo proporciona. O aprofundamento da razão pela qual essa família não acompanha a gestante deixa de ser investigado e analisado, portanto o aluno fica com uma visão parcial do conhecimento, há, portanto uma fragmentação do saber.

Conforme compreendido por MIOTO (1999), a concepção de família não pode estar vinculada a uma estrutura fechada. $O$ fato das pessoas viverem na mesma casa não é afirmativo de que esta seja uma definição de família, mesmo porque, as famílias têm uma 
característica heterogênea estabelecem diferentes relações de afeto e poder no seu interior, que têm como causa as diferenças de classes sociais e culturais, além da peculiaridade de organização de cada família.

Entende-se que estas questões devem ser discutidas e exploradas com os alunos para que esses possam ter uma visão do todo e não somente de um caso isolado e para isso é, necessário um suporte teórico que possa dar sustentação para tal, que se realizado somente em Ensino Clínico fica prejudicado. A prática humana, como bem comentada por LUCKESI (1994), é a mediadora da educação dentro de uma concepção teórica e tem como articuladora a pedagogia, a qual ordena os elementos que direcionam a prática educacional. Outro ponto bastante interessante é o que ocorre na disciplina em que a pediatria é trabalhada. É do entendimento do docente que não existe cuidado sem família, pois a criança não o poderia fazer sozinha, no entanto, mesmo com essa compreensão e valorizando a importância da família na assistência à criança, o enfoque maior sobre o tema Atenção à Saúde da Família fica a cargo do ensino clínico. O aluno vai a campo trabalhar família, mas não tem uma sedimentação teórica prévia a respeito de família e/ou ASF

Verifica-se que o corpo teórico é construído de acordo com as circunstâncias reais apresentadas no campo. O aluno aprende a pensar a ASF quando em contato com a realidade. Entende-se que o ensino prático faz parte do processo ensino-aprendizagem, no entanto, há necessidade de reflexão sobre essa realidade para, então, compreendê-la e aprendê-la e, se necessário, transformá-la. WACHOWICZ (2001, p. 4244) aborda esse tema com muita propriedade ao afirmar que "Para o método dialético, a realidade não pode ser diretamente apreendida pelo pensamento, devendo ser mediatizada por um processo de reflexão. A mediação é feita pela abstração e, portanto é ali, na abstração, o lugar da teoria" e conclui "Esse caminho, do abstrato para o concreto, é que estabelece a verdadeira relação entre teoria e prática: o caminho de uma reflexão que atinge o sentido da realidade porque constrói novamente no pensamento e pelo pensamento".

Conforme bem colocado por GADOTTI (2001), o homem que se utiliza das suas funções cerebrais como complemento do trabalho manual, torna-se consciente do processo de trabalho que desempenha e com isso domina o instrumento que utiliza e, portanto, não é dominado por ele. Essa colocação do autor, no sentido de que o profissional Enfermeiro tem que ter na sua formação uma teoria que possibilite uma boa prática, com consciência desse processo e que não seja uma prática voltada para o hábito, além de se concordar com ela, entende-se ainda, que assim possibilita ao profissional Enfermeiro dominar o seu processo de trabalho e utilizar os instrumentos disponíveis para tal com consciência crítica e reflexiva sobre o seu fazer.

Essa questão remete aos escritos, que foram citados na íntegra, elaborados por MIZUKAMI (1986, p.4), quando afirma que no ensino tradicional "O aluno que adquiriu o hábito ou que 'aprendeu' apresenta, com freqüência, compreensão apenas parcial”. A ação pedagógica tem que ser crítica e reflexiva, se pretende ter uma ação educativa de alto nível de consciência e para isso se estabelece uma relação entre a educação e a filosofia no processo de indagar quem é o educador, qual o seu papel no mundo, a sociedade o que é, o que pretende e qual deve ser a finalidade da ação pedagógica. Essa reflexão filosófica subsidia a ação pedagógica consciente, para que não se caia no senso comum, que é caracterizado pelo nosso dia-a-dia num espaço limitado e restrito levando a uma visão acrítica dessa vivência, como bem analisado por LUCKESI (1994).

Nesse sentido entende-se que conteúdos abordados somente em ensino clínico não oportunizam a discussão reflexiva que é enriquecedora para a construção do conhecimento, além de limitar o aluno a uma situação específica de campo, que pode ser levada por este como um modelo, um padrão a ser seguido, sem reflexão, além de se correr o risco de não sair do senso comum. O ensino clínico aparece como um meio de suprir a falta do conteúdo da ASF e há uma tentativa de preencher essa lacuna com as oportunidades que eventualmente surgem no decorrer da prática, seja esta prática exercida no hospital ou na Unidade de Saúde. Parece haver uma concordância dos docentes nesse aspecto. Pois, conforme seus relatos a ASF, a família surge somente no enfrentamento prático. Local esse em que inevitavelmente os alunos deparam-se com o familiar. Um espaço pequeno e limitado à determinada especialidade para o ensino e aprendizagem sobre Família e ASF. Para finalizar a análise dessa categoria, vamos expor o diálogo entre a pesquisadora e uma das docentes, ocorrido na reunião do grupo focal no dia 29/06/04, ao perguntar se a ASF era abordada em sua disciplina:

[...] Dessas 160 horas com esse título a gente só encontra uma referência a família, que não é família, é familiar: Planejamento familiar, mas que eu posso dizer que ele é dado numa perspectiva muito individual, como a mulher sendo a responsável por esse planejamento, quando na verdade a gente tem que inserir o companheiro dela. Então o que eu entendo.. O que foi a sua pergunta mesmo?(PROFESSOR, 5).

A Atenção à Saúde da Família é abordada dentro dos seus conteúdos? Como? (J ACOPETTI). 
Não! Nem dos meus, nem dos meus colegas, pelo que eu estou vendo aqui (Plano de Ensino), é claro que existe essa face de 160 horas de aula teórica e existe lá, as outra de parte de prática. Agora se eu acho, quando eu entendo que você trabalha conteúdo de família, você tem que trabalhar o contexto de família. Família monoparental, família reconstituída, né? Os diversos tipos de família. Isso eu posso te garantir que não é dado, né? Na verdade e nem o contrário, porque você tem a família no ambiente nosso do ensino clínico e isso poderia vir para o conteúdo teórico, porque na verdade aparece na sala de aula todo o tempo. Você esta apresentando o conteúdo, fazendo uma discussão de conteúdo, via de regra, você, faz um gancho com as coisas que aconteceram no ensino clínico, mais assim, então, ele é pontual. Olha tem exceção daquela família, mas a família..., mas a família sendo dada como uma unidade e considerada no contexto da disciplina ela não existe ( PROFESSOR 5).

Percebe-se nessa fala que a docente foi categórica na sua afirmação quanto a ausência nos seus conteúdos ministrados referentes à ASF, e dos seus colegas e a partir do grupo focal faz uma análise crítica das disciplinas no geral. No entanto no inicio das reuniões o discurso dessa docente era de que a família "estava muito presente" na sua disciplina. Esta fala não foi contestada por nenhum dos participantes do grupo focal, o que nos leva a concluir que a ASF não é contemplada sistematicamente, nas várias disciplinas profissionalizantes ministradas pelos docentes participantes desta pesquisa.

\section{Práticas Pedagógicas - Reorganização.}

Essa categoria teve sua origem na temática: Refletindo e Reorganizando a Prática Pedagógica, abstraída dos discursos proferidos pelos docentes sujeitos dessa pesquisa. Agrupou-se as respostas que mais se aproximaram e, como ocorreu nas categorias anteriores, sem perder de vista o(s) objetivo (os) da pesquisa.

Nessa categoria analisarmos as reflexões feitas pelos docentes sobre como reorganizar sua prática de maneira a contemplar uma abordagem na Atenção à Saúde da Família.

Os docentes chegaram a essa reflexão após várias reuniões do grupo focal, em que foram discutidos os conteúdos por eles ministrados, sua prática, suas dificuldades e a importância do conhecimento sobre a Atenção à Saúde da Família na formação do profissional Enfermeiro para sua inserção nas disciplinas profissionalizantes do Curso de Graduação em Enfermagem da Universidade Tuiuti do Paraná.

A reorganização da prática com uma abordagem a Atenção à Saúde da Família foi uma construção coletiva entre os participantes da pesquisa e consensual: os mesmos opinaram e indicaram os caminhos a serem percorridos para essa reorganização da prática docente, conforme proposto por esta pesquisa no que se refere aos aspectos metodológicos.

Ressalta-se que antes dessa reorganização os docentes solicitaram da pesquisadora uma exposição teórica sobre conceitos contemporâneos de Família, assim como referencial teórico que lhes dessem subsídios para essa reorganização. O que foi atendido por entender-se que a transmissão do conhecimento fazse coletivamente e que o conhecimento deve ser socializado.

No decorrer dessa reorganização da prática pedagógica, percebeu-se que os docentes passaram a fazer uma reflexão sobre a influência da sua formação técnica no decorrer de sua graduação e que isso, de certa forma, estava sendo reproduzido para os seus alunos. O depoimento abaixo foi acompanhado pelos demais participantes que sinalizaram afirmativamente movimentando suas cabeças, demonstrando concordância com o que estava sendo exposto:

Só para complementar o que eles falaram. Eu volto a dizer JACOPETTI, acho que já falei isso em outras reuniões, a dificuldade maior de você conseguir abordar isso na tua disciplina é justamente você enquanto indivíduo, enquanto Enfermeiro, acreditar naquilo que você esta falando, porque se você pensar isso não fez parte da minha formação e acredito que da de ninguém aqui [...] (Reunião do Grupo Focal do dia 29/06/04, PROFESSOR 9).

Pode-se claramente deduzir do exposto acima que a prática pedagógica exercida pelo professor é influenciada pela sua formação técnica que não the possibilitou uma visão de mundo mais ampla no que se refere às relações humanas, portanto o ponto inicial para uma reorganização do plano de ensino tem que ser internalizada por aquele que exerce a docência, para que essa realidade possa ser modificada. Para que não se tenha a reprodução desse modelo e considerando-se que os graduandos de hoje serão os profissionais de amanhã, aqueles que estarão tanto na "assistência" direta às pessoas, família e comunidade, como também exercendo a docência e, portanto, participantes na formação de uma nova geração de profissionais, é preciso convencer, fazer com que haja apropriação pelos alunos da necessidade de uma nova visão para a ASF. 
Observa-se, ainda, que falta clareza sobre o conhecimento do objeto de trabalho do Enfermeiro pelos docentes, pois o conhecimento permite que o profissional saiba o propósito de sua profissão e que esta não é meramente técnica, mas sim que a técnica é apenas um instrumento do seu processo de trabalho. Os docentes precisam tomar ciência dos diferentes processos de trabalho que compõe o processo de trabalho do Enfermeiro, para que possam contribuir na formação de um profissional mais crítico e ciente do seu saber-fazer.

LEOPARDI et al (2001) esclarecem que o trabalhador apreende o seu objeto de trabalho de uma maneira muito individual e, portanto, aí está a diferenciação da atuação de cada profissional, pois cada profissional escolhe instrumentos e métodos de atuação adequados para uma atividade específica. A trajetória do ensino da Enfermagem no Brasil, como claramente colocada por RIZZOTTO (1999), destaca que a formação do Enfermeiro sofreu influência da medicina, por conseguinte de um ensino centrado na unicausalidade do processo saúde-doença. A formação do Enfermeiro está impregnada do pensamento positivista da medicina, o que faz com que ocorra uma valorização das técnicas, das doenças e com isso distancia o profissional Enfermeiro do seu objeto de trabalho e conseqüentemente do seu processo.

A falta de conhecimento do objeto de trabalho do Enfermeiro, aliada a tradição histórica do ensino de Enfermagem no Brasil, centrado na unicausalidade da doença, no hospital e na valorização dos procedimentos técnicos não absorve a Atenção à Saúde da Família como parte de uma abordagem na formação do profissional Enfermeiro. Apreendeu-se, ainda, através dos discursos dos docentes, a preocupação em buscar um referencial teórico que possibilite subsidiar e ampliar os seus conhecimentos para as questões de família e uma posterior inserção de conteúdos nos seus Planos de Ensino. Assim:

Eu acho que através dessas leituras que a JACOPETTI né vai providenciar para gente ,isso vai nos auxiliar sabe a pensar que a gente tenha consciência que pode ser assim, a gente tenha consciência que dá para fazer isso, só não sabe ainda como, né, Então a partir dessas leituras a gente vai conseguir eu acho... eu acho não , eu tenho certeza de que vai, né? Eu acho que na verdade, assim, acredito muito nisso, né? A partir que os professores acreditem que pode acontecer a gente pó,r né, em prática que vai acontecer né? Mas a gente tem que ainda entender como que pode ser isso, né? (Reunião de 06/07/04, PROFESSOR 9).
A fundamentação teórica foi o marco inicial para a reorganização das práticas pedagógica para uma abordagem na ASF. Porque os professores participantes da pesquisa tinham certa insegurança na forma de como inserir a abordagem na ASF, por faltar-lhes subsídios teóricos para essa construção. Isso fica visível ao observar-se como se expressam:

Acho que a gente podia resgatar começo reconstituir já viu né?O que é a saúde e depois tentar conceituar ou contar o que é família né?(Reunião de 06/07/04, PROFESSOR 3).

Uma coisa que precisa não ser só discutida, mas tem que ser fundamentada, como o PROFESSOR 3 diz, tem que dar definitivamente conceitos realmente que possam transformar aquela idéia de percepção no começo em um conhecimento concreto ou um fazer depois concreto, uma coisa mais.....(Reunião do dia 29/06/04, PROFESSOR 6).

Acho que o problema é que não temos uma base teórica, se você não tem uma base teórica, entendeu? Aquilo vai da compreensão de quem esta conduzindo a discussão ou da situação que está acontecendo...(Reunião do dia 29/06/04, PROFESSOR 5).

Acredita-se que a abordagem da ASF possa não ter sido amplamente incorporada na prática dos docentes por falta de uma fundamentação teórica que Ihes proporcionasse uma reflexão mais aprofundada sobre o tema. Percebe-se, ainda, que a partir do momento em que estes docentes tomaram ciência do referencial teórico a intenção de introduzir o conteúdo da ASF em suas disciplinas foi tomando corpo.

Houve uma percepção pelos docentes que desconheciam a fundamentação teórica, embora o senso comum thes revelasse a importância da sua inserção nos conteúdos ministrados. Houve uma preocupação em saber como fazer e como integrar os conteúdos por eles ministrados, agora já com uma abordagem na ASF, de maneira que houvesse uma continuidade dos conteúdos por eles selecionados para a construção do conhecimento dos alunos e que estes pudessem agregar os conhecimentos adquiridos em outras disciplinas, em diferentes períodos, aos novos conhecimentos, proporcionando a seqüência do processo ensino-aprendizagem dos mesmos. Percebeuse, e isso é possível acompanhar através das falas, o dinâmico processo de produção do grupo:

Eu estava aqui pensando com a PROFESSORA 7 , que na verdade a gente tem um núcleo básico e que a gente tem que se aproximar desse núcleo para colocar as demandas nossas, né? 
Porque uma andorinha não faz verão, por exemplo, temas tratados por um professor ele se esvazia na seqüência (Reunião de 29/06/04, PROFESSOR 5)

Então isso eu acho que vai sendo assim, a cada disciplina, a cada ano que ele passar, são várias disciplinas ele vai acrescendo a importância da família, a incorporação da família naquilo que ele esta aprendendo. Então a família na Saúde Coletiva, né? Mais não vai ser só a Saúde Coletiva. Ele vai só acrescentar [...](Reunião de 29/06/04, PROFESSOR 7)

Em cima disso que vocês estão falando a inserção da saúde da família entraria no seu plano de ensino? (Reunião de 29/06/04, JACOPETTI).

Tem que entrar, porque na verdade eu não sei como isso seria abordado, porque eu já estou pensando que ele deveria ser uma coisa de complementaridade, mais o indivíduo não está isolado (Reunião de 29/06/04, PROFESSOR 5)

Percebe - se nesse diálogo que os docentes sentem a falta de um gancho entre as disciplinas para dar sentido aos conteúdos ministrados. Essa ausência de complementaridade faz com que sintam que seus conteúdos perdem-se ao longo do curso. Esse gancho proporcionaria aos alunos um ensino-aprendizado com coerência de conteúdos e não dicotomizado, ou seja, conteúdos que se inter-relacionam entre proporcionando uma clareza maior sobre os conteúdos apreendidos, nas diversas disciplinas profissionalizantes. Os docentes percebem que a abordagem familiar pode ser realizada independentemente do conteúdo ou da especialidade que está sendo ministrada, pois a família é parte do individuo e vice-versa, logo é necessário abordar a ASF para dar suporte aos familiares no cuidado e na condução de uma situação específica em que haja o envolvimento de um dos seus membros no processo saúde-doença.

Os docentes, na nossa ótica, passaram por um momento de desconstrução das suas práticas para uma nova construção, diante dessa nova proposta para uma abordagem na ASF. LUNARDI \& BORDA (1998) apontam com muita propriedade que é necessário ao docente colocar-se na posição de Enfermeiro na "assistência" e refletir sobre a "assistência" prestada, de maneira a criticar e aventar novas possibilidades quanto esse saber-fazer. Esse foi o momento de reflexão e discussão para a re-elaboração do plano de ensino das disciplinas profissionalizantes para a implantação da atenção à Saúde da Família , conforme proposto nesta pesquisa como um dos objetivos a serem estudados.
ATENÇÃO À SAÚDE DA FAMÍLIA - INSERÇÃO NAS DISCIPLINAS.

A re-elaboração dos planos de ensino realizada pelos docentes participantes da pesquisa, parte do que eles denominaram de Estrutura Organizacional da Inserção da Saúde da Família em diferentes Níveis de Complexidade de Atenção à Saúde da Família, tendo em vista a abordagem da Atenção à Saúde da Família. A reconstrução foi realizada em conjunto com os docentes no decorrer das reuniões com o grupo focal. Alguns docentes desistiram da participação por motivos de trabalho e outros não expressaram a razão de sua ausência, respeitam-se suas motivações.

Entretanto, os docentes que participaram dessa re - elaboração foram os mesmos desde o início do trabalho de campo. Fechou-se o grupo focal com cinco participantes, sendo que dois deles não estiveram presentes na reunião no dia em o grupo concluiu a reelaboração do Plano de Ensino. À medida que ia-se debatendo, em cada reunião do grupo focal, sobre a Atenção à Saúde da Família como uma possível abordagem para as disciplinas profissionalizante, ministrada pelos participantes, percebeu-se que esses tentavam encontrar um caminho para inserir a ASF nos seus Planos de Ensino. Far-se-à a transcrição da seqüência das falas, da reunião do grupo focal ocorrida no dia $17 / 08 / 4$, em que os docentes fazem um esboço de como inserir a Atenção à Saúde da Família em suas disciplinas:

Então para esse semestre nós disciplina da saúde do adulto idoso ,nós modificamos a ementa e colocamos Atenção à Família né? Então nós já começamos a abordagem está abordando diversos né? Diversos conteúdos e começamos; fizemos a primeira abordagem...começou a falar do processo saúde doença e a gente fez a inserção da família, da coletividade $[. .$.$] ( PROFESSOR 4).$

[...] os alunos iniciaram uma leitura de vários textos que falavam desse trabalho da inserção da família na assistência né? [...] e agora o próximo passo a gente termina o ensino clínico agora e volta para a teoria e a gente continua essa inserção da família em todos os assuntos que nós vamos abordar então agora a gente inicia assim as patologias do adulto né? Tem uma que vai tentar ...assim abordar né? O trabalho com a família junto à prevenção. Atenção a essas doenças. (PROFESSOR 9).

Entende-se, a partir dessas falas dos docentes, que o processo de inserção à Saúde da Família teve seu início,pois os docentes começam a introduzir a família, 
mesmo antes do término de nossas reuniões do grupo focal. Na medida em que avançam as discussões novas idéias surgem para inserção da Atenção à Saúde da Família, nas disciplinas dos respectivos participantes. Percebe-se, ainda, que os docentes começam a buscar por referencial teórico que lhes proporcione sustentação para essa inserção, conforme o exposto abaixo:

A gente começou agora com isso, então a gente começou com todos os conceitos de família né?Da família de hoje em dia da importância da família no processo da saúde, por isso que gerou bastante discussão. O papel da mãe o papel do pai, tudo isso então a partir de agora eu acho que isso deveria ser trabalhado em outros anos. (Reunião de 17/08/04, PROFESSOR 9).

Hum. Hum. E é assim como? (Reunião de 17/08/04, JACOPETTI).

A proposta para nossa disciplina ainda não saiu do papel, a gente entra com teoria de novo agora, mas a gente entra agora na área de patologia, né? O paciente é diabético, então a gente vai trabalhar com a assistência primária, secundária e terciária com o diabético né? Então a gente vai puxar sempre a família na assistência primária, e a família na secundária né? Então a gente vai tentar dar esse enfoque, não sei se vai dar certo é uma experiência que a gente vai falar para vocês na próxima reunião. (Reunião de 17/08/04, PROFESSOR 9).

[...] já coloquei nesse semestre, colocando o processo parto e nascimento e a inserção da família. O parto é um evento social, então se trata o parto como evento social, o primeiro grupo a se dar o nascimento deve ser a família, né? Então eu estou trazendo hoje, hoje até na aula eu estava dando mecanismo de parto, tal, já trouxe quando nasceu o bebê já trouxe a transparência com a família, sendo recebida pela família e não pelo profissional, que claro você faz uma ponte em cima disso, mas ele já começa a enxergar quem... Então vamos ter que inserir que a gente não pode trabalhar com uma coisa se não trabalhar com o todo, se não fica solto, se torna crítica, que família que é essa, acha que a família é nuclear, tem família de homossexual, e a gente tem que tratar todas essas. Então eu acho que o curso precisa assumir a margem conceitual, e a gente mostrando para eles as famílias que a gente vai encontrando no ensino clínico, família deles família sua, gera discussão porque ele já se inseriu. Na hora que ele se insere não tem jeito eles percebem que... (Reunião de 17/08/04, PROFESSOR 5).
Então a minha proposta para a reformulação, ela começaria na própria aula inaugural [...] eu acrescentaria metodologia de ensino baseado na saúde da família: breve resgate conceitual e assistência voltada à abordagem familiar. (Reunião de 31/087/04, PROFESSOR 2).

\section{E a professora prossegue:}

"começando por você, lá pelo primeiro ano, como já estão uma das opiniões que eu tenho é começar por você, entendeu, por exemplo, essa inserção de família, essa questão conceitual que você coloca." (Reunião de 17/08/04, PROFESSOR 2).

Eu acho que a gente tem que construi um eixo estrutural, né, um eixo mesmo, um desenho, um desenho, sabe, não sei como se chama, desenho estratégico. (Reunião de 14/09/04, PROFESSOR 2).

Por onde permeiam todas as disciplinas. (Reunião de 14/09/04, PROFESSOR 9).

Dar um esqueleto, um tronco da árvore, entendeu? $E$ depois cada disciplina põe sua, construir um desenho, um desenho mesmo. (Reunião de 14/09/04, PROFESSOR 2).

Por ano mesmo, primeiro, segundo terceiro, que contemple cada disciplina, por que lembra que a gente já tinha comentado com você que a gente, até porque é você que dá no primeiro semestre, segundo semestre, que você entra nessa parte da atenção a família, que você que inicia essa coluna vertebral, né Então a gente precisa estar discutindo, né? E montando isso junto, justamente para você desmembrar né? o que vai competir a cada ano, a cada disciplina. Mas a gente fazer isso em cima sim de uma teoria comum, né? Então assim a gente vai seguir a tal teoria, então todos os professores têm que seguir aquela teoria né? Independente da tua área, do teu campo de atuação. Né? ( Reunião de 14/09/04, PROFESSOR 9).

Então, por exemplo, né esse eixo central aqui, seria a Saúde da Família né, então olhe que interessante. A saúde da família, então quando eu tenho aqui, por exemplo, Saúde do Adulto Idoso ele faz ligação com esse eixo central com da Saúde da Família, que é essa extensão aqui, e ele também é o gancho da saúde Materno Infantil, que também é o gancho da Semiotécnica, daí tem que pegar a seqüência lá, né. Então as áreas o desenho curricular expressa uma importante coligação entre o eixo principal, a estrutura mestra trabalho, que essa daqui, e as disciplinas adjacentes. Está vendo? Então ele 
liga aqui, saúde da Família, Materno vai esta $r$ ligando aqui, eu vou eu vou fazer isso aqui. Então é assim o que o que eu tinha que eu tinha efetivamente pensado, pela dificuldade de informática mesmo eu não consegui construir né, porque é essas esferas na internet na opção que eu cliquei ela se sobrepõe uma em cima da outra e a minha idéia é que o eixo a ligação entre uma esfera e outra fosse visível porque daí iria dar noção de integração. Aí pensei nessas setas trifocada assim três eixos né juntamente dando a idéia que daria se essas esferas aparececem interligadas então no centro dessa seta eu coloco a integração e a integração de três eixos da Saúde da Família né da Introdução da Saúde da Família com a disciplina, com a disciplina do respectivo professor né integrando com disciplinas anteriores e posteriores. Então, por exemplo, na Saúde do Adulto e Idoso nós a minha disciplina a Materno recebe alunos que a sua última passada foi pela Saúde de Adulto Idoso, então a materno faz integração com Adulto Idoso mas que tenham um eixo central também vem do Adulto Idoso que é a Introdução a Saúde da Família. Então a proposta seguinte, talvez não sei o que vocês acham é que saísse mais um seguimento de cada uma das disciplina indicando seus focos de integração da saúde da família com a própria disciplina, então por exemplo aqui saúde adulto idoso vocês trabalham em quatro, então adulto idoso, centro cirúrgico. Aliás, não descrever tudo que é passado em centro cirúrgico, mas por exemplo, família , isso família e centro cirúrgico. É é idoso lá como é que vocês passam lá 0 ... (Reunião de 21/09/04, PROFESSOR 2).

Processo de envelhecimento, que nos temos agora né como é feito, processo de envelhecimento e como é que é... a família, trabalhando a família como cuidador né no processo de envelhecimento então daí pra ter o eixo. (Reunião de 21/09/04, PROFESSOR 4).

À medida que os docentes foram elaborando suas idéias, estas foram colocadas em um papel em forma de desenho, que denominaram de Estrutura Organizacional da inserção da Atenção à Saúde da família nas Disciplinas Profissionalizantes. Para demonstrar como ficaria a integração entre as mesmas. Os conteúdos equivalentes a cada disciplina seria mantido, no entanto agora, com uma abordagem na Atenção à Saúde da Família.

A disciplina Introdução à Saúde da Família, ministrada no segundo período do Curso de Graduação em Enfermagem da Universidade Tuiuti do Paraná, foi considerada pelos docentes como o eixo integrador das demais disciplinas profissionalizantes. Essa disciplina foi considerada o ponto de partida conceitual e filosófico sobre família, além dos aspectos técnicos, de como realizar uma Avaliação e Entrevista de Enfermagem às famílias.

Assim, a cada ano os docentes acrescentariam em seus conteúdos novos conhecimentos sobre a ASF, de forma a agregar aqueles apropriados anteriormente. Os docentes incluíram todas as disciplinas profissionalizantes do curso, no entanto, torna-se a ressaltar que a participação efetiva na re-elaboração do Plano de Ensino não contou com a participação de todos os docentes do Curso de Graduação em Enfermagem.Os docentes deixaram claro que devem ter um referencial teórico para dar sustentação e fundamentação aos conteúdos por eles ministrados para a inserção da abordagem à Atenção à Saúde da Família. Ressaltaram a necessidade da integração entre as disciplinas e de um eixo integrador entre elas, de maneira a possibilitar a segmentação dos conteúdos ministrados no decorrer do curso. Mantiveram-se atentos e muito motivados para aprender e para mudar sua abordagem no contexto da sala de aula.

Sugeriu-se, portanto, que a Atenção à Saúde da Família deve ser inserida no Projeto Político Pedagógico da Instituição e que todas as disciplinas profissionalizantes abordem a família em seus conteúdos, de maneira que o aluno possa apreender sobre os cuidados com a saúde da família no decorrer da sua formação. Acredita- se que se a ASF estiver inserida no Projeto Político Pedagógico do Curso e não somente no Plano de Ensino dos docentes, estes passarão a ter um maior comprometimento com a problemática abordada, uma garantia maior de que o tema será abordado.

Embora tenha-se realizado uma construção conjunta com os docentes das disciplinas profissionalizantes para a inserção à Atenção à Saúde da Família no Curso de Enfermagem da Universidade Tuiuti do Paraná, deixa-se aqui algumas recomendações, que acredita-se possam vir a contribuir na formação do profissional Enfermeiro no que se refere ao seu preparo para atuar junto às famílias que tenham um ou mais de seus membros afetados por um problema de saúde.

Nossa recomendação é que os docentes tenham uma base conceitual sobre família no sentido de entender que tipos de família estarão "assistindo". Adotou-se, como conceito de família, o proposto pelas docentes canadenses da Universidade de Calgary, por ser um conceito mais abrangente sobre família: "A família é quem seus membros dizem que são" (WRIGHT e LEAHEY, 2002, p.68). Entende-se que esse conceito considera as particularidades das pessoas e com isto a 
liberdade de escolha do seu cuidador, quando no acometimento de um problema de saúde. Essa visão torna possível ao profissional Enfermeiro ver a família de uma forma mais ampla, sem com isso desconsiderar o conceito de família adotado pelo profissional, enquanto membro de uma família.

Um conceito claro sobre família por parte do profissional Enfermeiro é o que definirá a maneira de ver e assistir as famílias no seu processo de saúde-doença. Entende-se que as avaliações, entrevistas e cuidados a serem prestados na Atenção à Saúde da Família têm como linha mestra o que se pensa sobre elas e delas e, conseqüentemente, isso se reflete na "assistência" dispensada a elas. Recomenda-se, ainda, que os docentes façam uma reavaliação dos seus conteúdos ministrados e verifiquem se há uma integração dos mesmos com as demais disciplinas, abrindo um leque para a construção do conhecimento sobre famílias e suas peculiaridades. Acredita-se nesta possibilidade de reflexão sobre a influência da família no processo saúdedoença dos seus membros. Essa reflexão deve ser feita em conjunto, socializando o conhecimento para uma maior elaboração dos conteúdos a serem ministrados e abordados de forma a integrar a família na "assistência" do futuro profissional Enfermeiro.

A Atenção a Saúde da Família deve ter em sua abordagem os aspectos teóricos para a realização de uma prática fundamentada. Recomenda-se que teoria e prática caminhem paralelamente e que a família e a Atenção a ela, seja contemplada antes mesmo do aluno entrar em contato com elas nas disciplinas práticas. Acredita-se, ainda, que é necessário estar explícito no Plano de Ensino o momento das abordagens na Atenção a Saúde da Família nos conteúdos a serem ministrados pelas disciplinas profissionalizantes, na intenção de que o docente visualize o seu compromisso proposto e com isso o realize de fato.

\section{CONSIDERAÇÕES FINAIS}

A escolha do objeto desta pesquisa surgiu de algumas inquietações por parte da pesquisadora. Como membro do corpo docente da Universidade Tuiuti do Paraná e professora das disciplinas de Saúde Coletiva e Introdução a Saúde da Família, percebeu a falta de consonância na abordagem de Atenção à Saúde da Família entre as demais disciplinas profissionalizantes.

A disciplina de Introdução à Saúde da Família, ministrada no segundo período do Curso de Enfermagem, mostrou a necessidade de se ter uma abordagem mais consistente quanto aos conceitos sobre família. Os alunos trazem conceitos de uma família nuclear burguesa o que do ponto de vista desta pesquisa limita a Assistência de Enfermagem às famílias. Por isso acredita-se que o futuro profissional
Enfermeiro tem que ter um conceito claro sobre família, para então poder assisti-la em suas necessidades no processo saúde-doença. Além da ênfase na conceituação, os alunos devem conhecer como as famílias organizam-se, desorganizam-se e reorganizamse de maneira muito particular e descartar a idéia de uma família estruturada ou desestruturada, com isso rompendo com as idéias pré-concebidas de uma família nuclear burguesa.

A família é tida como estrutura quando se encaixa dentro dos moldes pré-estabelecidos de uma sociedade e isso é ensinado nas escolas desde o Ensino Fundamental, o que leva os alunos a pensarem em uma família ideal, em um modelo padrão aceito pela sociedade.

A dinâmica familiar varia de acordo com os interesses das mesmas e organiza-se de maneira muito singular e, quando frente a um problema de saúde de qualquer um de seus membros, essa dinâmica sofre alterações que, muitas vezes, pode levar a situações de conflitos entre seus membros.

Quando se tem um profissional preparado, com capacidade de avaliar e intervir juntos às famílias, nas suas diferentes formas de se estruturar e nas diferentes dinâmicas inter-relacionais, há probabilidade de uma atuação mais efetiva por parte do Enfermeiro no processo saúde-doença, não só em relação ao indivíduo, mas também com a família ampliam-se consideravelmente.

Se for um profissional com visão reducionista de família, irá realizar uma avaliação e Intervenção de Enfermagem de acordo com o seu campo ótico e, como as reais necessidades de cada família ficam a critério da ótica unilateral do profissional, o atendimento será "reducionista". Portanto, essa formação, pela sua abrangência, não deve ficar a cargo de uma única disciplina, o que se verifica é a necessidade de uma interação com as demais disciplinas profissionalizantes do Curso.

A integração com as demais disciplinas possibilita ao aluno um ensino-aprendizagem conectado às diversas especialidades a serem apreendidas e maior consolidação dos conhecimentos já apreendidos. No entanto, é necessário que os docentes tenham um fio condutor que leve o aluno a perceber a trajetória realizada para a Atenção à Saúde da Família. Esse fio condutor tem que ser construído com base num referencial teórico escolhido pelos docentes que ministram as mais variadas disciplinas profissionalizantes no decorrer do Curso de Enfermagem. Sem essa integração de conteúdos e sem direcionamento por parte dos docentes os alunos passam a enxergar a família como um apêndice do processo saúde-doença ou, ainda, como não sendo de sua responsabilidade a saúde das famílias. 
Atualmente as Políticas Públicas de Saúde dão ênfase maior na Atenção à Saúde da Família, através do Programa de Saúde da Família (PSF). De fato o PSF é um Programa que veio contribuir no atendimento à saúde das famílias, sendo restrito às Unidades de Saúde da Família. Mas o que se compreende é que a Saúde da Família deve ser contemplada com ou sem o PSF, pois 0 atendimento às famílias não pode ficar à mercê de uma Unidade de Saúde que tenha o Programa como garantia para o seu atendimento. As famílias existem independentemente do Programa.

Ao refletir-se, sobre essa questão com maior profundidade, pergunta-se: será que as famílias que tem um de seus membros hospitalizados não carecem de atenção à sua Saúde como o proposto pelo PSF? As famílias só são percebidas na Atenção Primária à Saúde? A Família deixa de ser necessária para o restabelecimento de um de seus membros, quando não incluídas no PSF? Qual a diferença entre as famílias que têm um de seus membros hospitalizados e aquele que tem o atendimento ambulatorial ou domiciliário? A família muda, quando muda a complexidade da Atenção a Saúde? Os problemas familiares amenizam-se ou se tornam mais agudos, quando um de seus membros está hospitalizado? Precisamos de um Programa específico para perceber a existência da Família no processo saúde-doença? Só existe família porque existe o Programa ou o Programa só existe porque existe família?

Essas e muitas outras indagações ocorrem na tentativa de dar um suporte maior na ASF em qualquer nível de complexidade da "assistência". Responder a todas essas questões tão complexas foge ao âmbito desta pesquisa. Mas elas devem permear as reflexões dos docentes de Enfermagem que atuam na formação do futuro profissional Enfermeiro.

Entende-se que a abordagem Atenção à Saúde da Família deva se estender a todas as disciplinas profissionalizantes do Curso de Enfermagem, pois as pessoas, os pacientes e/ou clientes que ficam sob os cuidados do profissional Enfermeiro, quer estejam no hospital, na Unidade de Saúde ou em suas casas, possuem uma família e têm uma história de vida junto a seus familiares.

Diante de todas essas inquietações trabalhamos junto ao corpo docente da Universidade Tuiuti do Paraná, das disciplinas profissionalizantes do Curso de Enfermagem para a implementação da ASF.

Constatou-se no decorrer da pesquisa que os docentes não traziam uma fundamentação teórica suficiente para alicerçar um conceito de família. O conhecimento advinha do senso comum e das suas experiências vividas em família. A Atenção à Saúde da Família era vista, por esses docentes, isoladamente, ou seja, um conteúdo a ser trabalhado nas disciplinas que abordam a coletividade, ou seja, Saúde Coletiva, ou ainda na disciplina específica: Introdução à Saúde da Família.

Quando se analisou os Planos de Ensino desses docentes envolvidos na pesquisa, constatou-se que a Atenção à Saúde da Família não era abordada de forma sistemática. Uma vez constatado o problema e debatido em várias reuniões pedagógicas com os demais membros do corpo docente, chegou-se a um consenso: de que é preciso trabalhar junto aos alunos a Atenção à Saúde da Família.

Esta pesquisa proporcionou uma satisfação muito grande, no que se refere ao trabalho em conjunto com os docentes da Universidade Tuiuti do Paraná, pois permitiu a troca de experiências e a construção um novo conhecimento a respeito da importância à Atenção à Saúde da Família no dia-a-dia do trabalho do Enfermeiro, além dos anseios sobre a formação desse profissional terem sido compartilhados.

Pode-se refletir sobre a prática docente e repensar a contribuição que oferece na formação do profissional Enfermeiro, tendo em vista a qualidade na "assistência" às famílias no processo-saúde doença e a importância de se manter uma família saudável no enfrentamento de um problema de saúde, quando um de seus membros adoece. Diante de tamanha responsabilidade dos docentes na formação do futuro profissional Enfermeiro, não é possível a acomodação. Precisa-se estar em permanente vigilância na busca da excelência desta formação e acredita-se que a ASF é uma possibilidade muito significativa para se atingir esse propósito.

Espera-se que esta pesquisa possa contribuir com os colegas docentes para um repensar sobre a sua prática pedagógica na formação do profissional Enfermeiro e assim colaborar com um preparo que o capacite suficiente e eficientemente para enfrentar o mundo do trabalho, suas contradições e conflitos, ainda mais em se tratando da Atenção à Saúde da Família.

\section{REFERÊNCIAS BIBLIOGRÁFICAS}

BOGDAN, R. BIKLEN, S. Investigação Qualitativa em Educação: uma introdução à teoria e aos métodos. Porto: Porto, 1991. 336 p.

BRASIL, Conselho Nacional de Educação. Câmara de Educação Superior. Resolução CNE/CES 3/2001. Diário Oficial da União, Brasília, 2001. Seção 1, p. 37. disponível em: http://portal.mec.gov.br. [acesso em 15 fev. de 2005].

CARVALHO, M. C. B. de. O lugar da família na política social. In: CARVALHO, M.C.B de et al. A família Contemporânea em Debate. São Paulo: EDUC/ Cortez, 2002. p. 15-22

CHIZZOTTI, A. Pesquisa em Ciências Humanas e Sociais. São Paulo: Cortez, 2000.164 p 
COSTA NETO, M. M da. Enfoque familiar na formação do Enfermeiro. Olho Mágico. Londrina, ano 6, n.22, p. 59, ago.2000.

FEUERWERKER, I. Estratégias de mudança da formação dos profissionais de saúde. Olho Mágico. Londrina. v.9, n.1, p.16-18, jan-abr. 2002.

FIOCRUZ, Gestão de saúde: curso de aperfeiçoamento para dirigentes municipais de saúde: programa de educação à distância. Planejamento da atenção à saúde. Módulo 7, Rio de Janeiro, 1998.

GADOTTI. M. concepção Dialética da educação: um estudo introdutório. 12 ed. São Paulo: Cortez, 2001, 182 p.

LAVRAS, C. O processo de formação de recursos humanos para o SUS na visão dos gestores municipais. Olho Mágico. Londrina. V.9, n.1 p.29-30, jan-abr. 2002.

LEOPARDI, T. M. et al Cuidado: objeto de Trabalho ou Objeto Epistemológico da Enfermagem? . Texto \& Contexto Enfermagem. Florianópolis, v. 10, n. 1, p. 3239, jan/abr. 2001.

LUNARDI, L. V.; BORDA, R. M. o Pensar e o Fazer da Prática pedagógica: A Busca de uma Nova Enfermeira. In: SAUPE, R. Educação em Enfermagem: da realidade construída às possibilidades de construção. Florianópolis: UFSC, 1998.

LUDKE, M.;ANDRÉ, M. E. D. A. Pesquisa em Educação : abordagens qualitativas São Paulo: Editora Pedagógica e Universitária Ltda, 1986. 99 p.

LUCKESI, C. C. Filosofia da Educação. 15. ed, São Paulo: Cortez, 1994. p.181.

MAZZOTTI, A. J. A; GEWANDSZNAJDER, F. O método nas Ciências naturais e Sociais. 2. ed. São Paulo: Pioneira Thomson Learning, 2001. 203 p.

MEIER, J. M.; KUDLOWIEZ, S. Grupo Focal: Uma Experiência Singular. Texto e Contexto Enfermagem. 2003. jul-set: 12(3): 394-9.

MINAYO, M. O Desfio do Conhecimento. 6. ed. Rio de Janeiro: Hucitec, 1999.

MIOTO, T. C. R. Famílias Hoje: O Começo da Conversa. Texto \& Contexto de Enfermagem: Família e Violência, Florianópolis, v. 8, n. 2, p. 211-219, mai/ago. 1999.

MIZUKAMI, N.G.M. Ensino: As Abordagens do Processo. 9 ed. São Paulo: EPU, 1986. 119 p.

RIZZOTTO, M. L. F. História da Enfermagem e sua Relação com a Saúde Pública. Goiânia: AB, 1999. 99 p.

PATTON, M. Q. Qualitative Evaluation and Research Methods. 2 ed. Califórnia: Sage Publication Ltda., 2002. $531 \mathrm{p}$.

POLIT, D. F; HUNGLER, B. P. Fundamentos de Pesquisa em Enfermagem. 3. ed. Porto Alegre: Artes Médicas Ltda, 1995.

RODRIGUES, P. S. M.; LEOPARDI, T. M. O Método de Análise: uma versão para enfermeiros. 1. ed. Fortaleza: Fundação Cearense de Pesquisa e Cultura, 1999. 118 p.
WACHOWICZ, A. L. O Método Dialético da educação Superior. In: CASTANHO, S. ; CASTANHO, E. M. Temas e Textos em Metodologia do Ensino Superior. 2. ed. Campinas: Papirus, 2001. p. 37-46.

WRIGHT, M. L.; LEAHEY. M. Enfermeiras e Famílias: Um Guia para Avaliação e Intervenção na Família. 3. ed. São Paulo: Roca, 2002, 327 p.

Texto recebido em 17/11 2005.

Publicação aprovada em 29/12/2005 